\title{
Giant Virchow- Robin spaces may play a role at headache attributed to hypoxia and/or hypercapnia
}

\author{
Dev Virchow-Robin aralıkları hipoksi ve/veya hiperkapniye bağlı baş ağrısında rol \\ oynayabilir
}

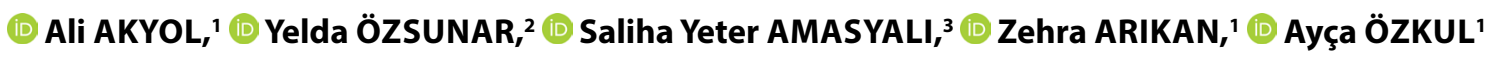

\begin{abstract}
Summary
According to the International Classification of Headache Disorders-3 beta version, headache attributed to hypoxia and/or hypercapnia is classified under the four titles: 10.1.1 High altitude headache, 10.1.2 Airplane travel associated headache, 10.1.3 Diving headache, and 10.1.4 Sleep apnea headache. Headache associated with airplane travel is encountered infrequently in our clinical practice and first reported in 2004 as a case in the literature. The pathophysiology of headache associated with airplane travel is not yet clear. We presented this case in the aspect of the patient having both airplane travel and high-altitude headaches and seen giant Virchow-Robin spaces in cranial MRI and disappearance of pain with a preventive treatment.

Keywords: Airplane travel associated headache; high-altitude headache; Virchow-Robin spaces.

Öz

IHS 2013-beta versiyonunda hipoksi veya hiperkapniye bağlı baş ağrıları 10.1.1 yüksek irtifa baş ağrısı, 10.1.2 uçak seyahatine bağlı baş ağrısı, 10.1.3 dalma baş ağrısı, 10.1.4 uyku apnesi baş ağrısı şeklinde alt gruplara ayrılmaktadır. Uçak seyahati esnasında ortaya çıkan baş ağııları sık karşılaşmadığımız baş ağıllarındandır. Literatürde ilk vaka 2004 yılında bildirilmiştir. Uçak seyahatine bağlı baş ağrısı patofizyolojisi henüz tam anlaşılamamıştır. Uçak seyahati ve yükseklik baş ağrılarının birlikte aynı olguda görülmesi, kranial MR' da geniş Virchow-Robin aralıklarının izlenmesi, önleyici atak tedavisi ile bu baş ağrılarının gelmemesi yönüyle hastamızı sunmayı uygun bulduk.
\end{abstract}

Anahtar sözcükler: Uçak seyahatine bağlı baş ağrısı; yüksek irtifa baş ağrısı; Virchow-Robin aralıkları.

\section{Introduction}

The airplane travel headache which is a rare type of headache first reported in 2004 as a case in the literature. It is increasingly seen in recent years, that's why there has been need to proposed diagnostic criteria for this type of headache..$^{[1,2]}$ Subsequently, it has been validated and included in last version of International Classification of Headache Disorders 3 (ICHD-3) beta version. ${ }^{[3]}$ There are only the case and case series exist in the literature about the airplane travel headache.

Here, we aimed to present a 41-year-old male with headache during and shortly after airplane travel which was unilateral, throbbing and stabbing at the frontal region that has not been experienced before. The patient also described the same headache during road trip at the highest altitude of the same destination. Different from the other airplane travel headache, in this case, there were giant Virchow-Robin spaces on cranial magnetic resonance imaging (MRI).

\section{Case Report}

A 41-year-old man had a history of headaches (4 times) during airplane travels for 1 year. The headache onset was sudden and very severe intensity. Headache was beginning after the plane left ground and while it was gaining altitude, a very severe throb-

\footnotetext{
'Department of Neurology, Adnan Menderes University Faculty of Medicine, Aydın, Turkey 2Department of Radiology, Adnan Menderes University Faculty of Medicine, Aydın, Turkey ${ }^{3}$ Division of Algology, Department of Physical Medicine and Rehabilitation, Adnan Menderes University Faculty of Medicine, Aydın, Turkey Submitted: 21.03.2017 Accepted after revision: 03.12.2018 Available online date: 11.12.2018
}

Correspondence: Dr. Ali Akyol. Adnan Menderes Üniversitesi Tıp Fakültesi, Nöroloji Anabilim Dalı, 09000 Aydın, Turkey. Phone: +90 - 256 - 4441256 e-mail: aakyol@adu.edu.tr

C) 2021 Turkish Society of Algology 
bing and stabbing pain was appearing in the right supraorbital field of forehead. However, it was rarely spreading parietooccipital regions. He described this as the most severe pain he had ever experienced. The mean severity was 10 on numeric rating scale (NRS). The intensity of headache was diminishing as the plane began to descent and subsided completely and spontaneously after landing. The pain was not associated with phono- or photophobia, nausea, vomiting, and autonomic symptoms such as rhinorrhea, tearing, lacrimating, and other ocular manifestations. The patient had no medical history of sinus problems and any medications. The family history has not shown prominent feature in terms of headaches. He smoked about 15-20 cigarettes per day for 20 years. There was no drug abuse but he was a social alcohol consumer (a glass raki which is Turkish alcohol, once a month). Blood pressure, routine blood tests, and physical and neurological examination were all normal. Brain MRI proved dilated Virchow-Robin spaces localized in the insular cortex and basal ganglia, bilaterally.

\section{Discussion}

Headache associated with airplane travel is encountered infrequently in our clinical practice. According to the ICHD-3 beta version, headache attributed to hypoxia and/or hypercapnia is classified under the four titles: 10.1.1 High altitude headache, 10.1.2 Airplane travel associated headache, 10.1.3 Diving headache, and 10.1.4 Sleep apnea headache. ${ }^{[3]}$ Our case was seemed to adapt with subtitle of 10.1.2 headache attributed to airplane travel. The updated ICHD-3 criteria are given in Table 1. In our case, the pain was radiated to contralateral side of the head. Pain shifting to contralateral side has been reported in approximately $10 \%$ of the cases between different flights in the literature.$^{[3]}$ Our patient's headache met for this diagnosis criteria for his all four boarding. In reported diagnostic criteria, the pain only occurs with boarding the plane.

Although there are many proposed mechanism, the pathophysiology of headache associated with airplane travel is not yet clear. ${ }^{[4]}$ Changes in nasal mucosa and sinuses such as mucosal edema may play a role in triggering headache during airplane travel. Variation of anatomical factors related to sinuses such as narrow frontal sinus outlet may also contribute to this mucosal changes. ${ }^{[4,5]}$ It is supposed that barotrauma caused by pressure changes within sinus cavities during take-off and landing could affect the ethmoidal nerves (branching from the ophthalmic nerve) or the nociceptors in the ethmoidal arteries, subsequently activating the trigeminovascular system which leads to headache. Furthermore, sensitization of trigeminal nerve endings due to any disorder in nasal and paranasal mucosa may cause similar maladaptation to pressure changes as well. ${ }^{[6,7]}$

Previously published data have shown that similar headaches commonly occur in both during descent from high altitudes and scuba diving. ${ }^{[1,8]}$ In concordance with this, our case was also another model of the coexistence of headache related to in two different conditions of altitude variation. Our patient was described the same headache related to airplane travel in his another travel by driving car at the highest point of the route between the same cities (Izmir Antalya route, Korkuteli district, altitude 1020 m). The pain was subsided with mountain descent and ceased in less than an hour. This pain was less severe (NRS: 9) with compared to airplane travel headache and it is not associated with nausea, vomiting, pallor, and allodynia. However, in this case, headache was occurred at a lower altitude than the ICHD-3 diagnostic criteria described (>2500 m). We supposed that the sudden occurrence and disappearance of headache were associated with altitude changes due to fast ascent and descent.

Coutinho and Pereira-Monteiro reported a case who had coexistence of headache related to in two different conditions of altitude variation that one of them was airplane headache and the other was altitude headache. Similar to our case, in this case, headache was also occurred at lower altitude $(2000 \mathrm{~m})$ than diagnostic criteria described. ${ }^{[3,7]}$ Rogers et al. ${ }^{[6]}$ claimed that headaches showing the same clinical features arising in different situations support the common pathophysiological mechanism. In our case, there was also coexistence of two different headaches (10.1.1 High-altitude headache and 10.1.2 Headache attributed to airplane travel) which support the possible common pathophysiology. The hypoxia which leads to increase in cerebral blood flow and based on this respond with vasodilatation in organism underlies the pathophysiology of airplane travel head- 
Table 1. International Headache Society diagnostic criteria for high-altitude headache and airplane travel associated headache

10.1.1. High-altitude headache

A. Headache fulfilling criterion $C$

B. Ascent to altitude above $2500 \mathrm{~m}$ has taken place

C. Evidence of causation demonstrated by at least two of the following:

1. Headache has developed in temporal relation to the ascent

2. Either or both of the following:

a) Headache has significantly worsened in parallel with continuing ascent

b) Headache has resolved within $24 \mathrm{~h}$ after descent to below $2500 \mathrm{~m}$

3. Headache has at least two of the following three characteristics:

a) Bilateral location

b) Mild or moderate intensity

c) Aggravated by exertion, movement, straining, coughing, and/or bending

D. Not better accounted for by another ICHD-3 diagnosis

\subsubsection{Headache attributed to airplane travel}

A. At least two episodes of headache fulfilling criterion $C$

B. The patient is travelling by airplane

C. Evidence of causation demonstrated by at least two of the following:

1. Headache has developed exclusively during airplane travel

2. Either or both of the following:

a) Headache has worsened in temporal relation to ascent after take-off and/or descent before landing of the airplane

b) Headache has spontaneously improved within 30 min after the ascent or descent of the airplane is completed

3. Headache is severe, with at least two of the following three characteristics:
a) Unilateral location
b) Orbitofrontal location (parietal spread may occur)
c) Jabbing or stabbing quality (pulsation may also occur)

D. Not better accounted for by another ICHD-3 diagnosis

ICHD-3: International Classification of Headache Disorders-3.

ache that increases with hypoxia and/or exposure to hypercapnia and regress with better environment.

The cranial MRI findings were normal in the first case of airplane travel headache in 2004 and in the subsequent reports. ${ }^{[6,7,9-15]}$ Whereas in our case, the wide Virchow-Robin spaces were found at insular cortex and basal ganglia in cranial MRI (Fig. 1). VirchowRobin areas are perivascular spaces that around small arteries and veins entering into brain from subarachnoid area, and generally, this finding is seen at any age which not lead to complaint. However, this situation can cause symptoms such as ataxia in accordance with where they settled and also precipitate headache frequently. This enlarged space can be

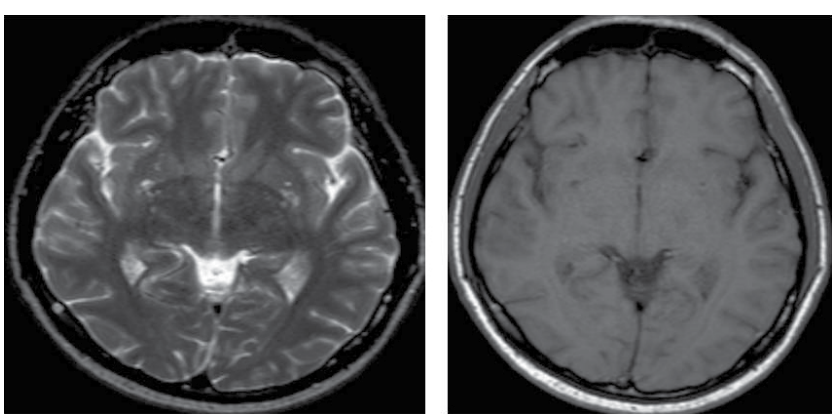

Figure 1. Giant Virchow-Robin spaces in the insular cortex and basal ganglia.

seen in migraine headaches and has been observed in our case at insular cortex which is a well-known brain region that plays a role in the evaluation of pain. [16-19] The wide Virchow-Robin spaces were reported in migraine headaches in the literature as well as in 
our case suffering from airplane travel headache and high-altitude headache suggested that the expansion of these spaces in vascular headache is related to intracranial pressure compliance.

\section{Conclusion}

Although there is the perception that airplane travel headache is a rare situation which existing with a few case reports in the literature, this condition might be more common than expected because of underdiagnosing. In addition, along with the clarification of the pathophysiology of this uncleared condition, it would be possible to develop effective prevention or treatment. ${ }^{[15]}$ After our recommendation to the patient to take indomethacin $(50 \mathrm{mg}) 1 \mathrm{~h}$ before the trip (both by airplane or car), he had never had headache of last six travels. We presented this case in the aspect of the patient having both airplane travel and high-altitude headaches which can be seen in the same patient, and it may be related with giant Virchow-Robin spaces in the brain, especially related with pain areas.

\section{Informed Consent: Written informed consent was obtained from the patient for the publication of the case report and the accompanying images.}

Conflict-of-interest issues regarding the authorship or article: None declared.

\section{Peer-rewiew: Externally peer-reviewed.}

\section{References}

1. Mainardi F, Maggioni F, Lisotto C, Zanchin G. Diagnosis and management of headache attributed to airplane travel. Curr Neurol Neurosci Rep 2013;13(3):335. [CrossRef]

2. Atkinson V, Lee L. An unusual case of an airplane headache. Headache 2004;44:438-9. [CrossRef]

3. Headache Classification Comittee of the International Headache Society (IHS). The International Classification of Headache Disorders, $3^{\text {th }}$ edition (beta version). Cephalalgia 2013;33(9):749-57. [CrossRef]

4. Berilgen MS, Mungen B. A new type of headache. Head- ache associated with airplane travel: Preliminary diagnostic criteria and possible mechanisms of aetiopathogenesis. Cephalalgia 2011;31(12):1266-73. [CrossRef]

5. Cherian A, Mathew M, lype T, Sandeep P, Jabeen A, Ayyappan K. Headache associated with airplane travel: A rare entity. Neurol India 2013;61(2):164-6. [CrossRef]

6. Rogers K, Rafiq N, Prabhakar P, Ahmed M. Childhood headache attributed to airplane travel: A case report. J Child Neurol 2015;30:764-6. [CrossRef]

7. Coutinho E, Pereira-Monteiro J. Bad trips: Airplane headache not just in airplanes? Cephalalgia 2008;28(9):986-7.

8. Kararizou E, Anagnoustou E, Paraskevas G, Vassilopoulou $\mathrm{SD}$, Naoumis D, Kararizos G, et al. Headache during airplane travel ("airplane headache"): First case in Greece. J Headache Pain 2011;12(4):489-91. [CrossRef]

9. Berilgen MS, Müngen B. Headache associated with airplane travel: Report of six cases. Cephalalgia 2006;26(6):707-11.

10. Evans RW, Purdy RA, Goodman SH. Airplane descent headaches. Headache 2007;47(5):719-23. [CrossRef]

11. Mainardi F, Lisotto C, Palestini C, Sarchielli P, Maggioni F, Zanchin G. Headache attributed to airplane travel ("airplane headache"): First Italian case. J Headache Pain 2007;8(3):196-9. [CrossRef]

12. Marchioretto F, Mainardi F, Zanchin G. Airplane headache: A neurologist's personal experience. Cephalalgia 2008;28(1):101.

13. Baldacci F, Lucetti C, Cipriani G, Dolciotti C, Bonuccelli $U$, Nuti A. Airplane headache with aura. Cephalalgia 2010;30(5):624-5. [CrossRef]

14. Domitrz I. Airplane headache: A further case report of a young man. J Headache Pain 2010;11(6):531-2. [CrossRef]

15. Azman F, Erkılınç B, Çabalar M, Çağırıcı S, Yayla V. A rarely known headache: Airplane travel headache. Agri 2017;29(1):47-8. [CrossRef]

16. Yılmaz M, Hazer DB, Çullu N, Deveer M, Gökkuş B, Palalı I. Ataxic gait due to giant cystic virchow-robin spaces: Case report. J Neurol Sci (Turkish) 2012;29(2):427-30.

17. Akar G, Eser M, Taşdemir SS, Gözke E. Giant virchow-robin spaces in a patient with migraine: Case report. Türk Klin J Neur 2015;10(1):36-8. [CrossRef]

18. Schick S, Gahleitner A, Wöber-Bingöl A, Wöber C, Ba-Ssalamah $A$, Schoder $M$, et al. Wirchow-Robin spaces in childhood migraine. Neuroradiology 1999;41(4):283-7. [CrossRef]

19. Machado MA Jr., Matos AS, Goyanna F, Barbosa VA, Vieira LC. Dilatation of Virchow-Robin spaces in patients with migraine. Arq Neuropsiquiatr 2001;59(2-A):206-9. [CrossRef] 